\title{
Ten Commandments of Physician Wellness
}

\author{
Edward J. Krall, MD
}

I report nearly $45 \%$ of doctors feel burnout in their work, more so than among other US workers. ${ }^{1}$ Burnout has serious consequences for physicians and patients including loss of professionalism, ${ }^{2}$ medical errors, ${ }^{3}$ decreased patient satisfaction, ${ }^{4}$ and even depression and suicidal ideation. ${ }^{5}$

Recently, in talking to a group of residents about burnout, I asked if they knew anyone in medicine who was happy. Only one of thirty-some aspiring doctors thought that one could find happiness in the practice of medicine. I was saddened for them, and what they saw in their future. I have worked in Physician Health for over 10 years as chair of a physician health committee. At times, I have felt like a medic on a battlefield caring for wounded and struggling colleagues. However, I have also known colleagues who continue to take care of patients and find meaning and joy.

There is a lot of press about the stress of practicing medicine, but less about the secrets of thriving. There is literature about resilience. $^{6-8}$ It has limitations, but several themes have emerged. Pulling together ideas from that literature and experience from my work with colleagues, I offer to residents these "Ten Commandments of Physician Wellness."

\section{I.Thou shall not expect someone else to reduce your stress.}

Do not expect a caring management to keep you comfortable. Ask not what any organization is doing to lower your stress, but rather take charge of your own wellbeing. To be sure, organizations have a role in improving practice design and efficiency and promoting meaning, ${ }^{9}$ but at the end of the day, you are the only one in your work situation who will or even can do much to lighten your psychological load.

\section{II.Thou shall not resist change.}

Physicians do not handle ambiguity or change well. They are controlling, compulsive, and prefer to do things their own way. ${ }^{10-12} \mathrm{I}$ have seen many colleagues get disgusted, demoralized, and doubtful about their future. They tend to be critical, conservative, and cautious and often waste more emotional energy hanging on to old habits and beliefs than it would take to embrace the changes. They end up doing only what it takes to get by and react by emotionally disconnecting from their work. If we are going to survive, we need to make the best of the situation.

Develop a sense of acceptance. Acceptance allows one to consider possibilities that may not align with preconceived notions. At the very least, it means temporarily becoming comfortable with the imperfect, undesirable, or uncontrollable. It is different from apathy. Apathy is a loss of passion and hope and reflects pathological pessimism. Acceptance represents hope, optimism, and faith. ${ }^{13}$

\section{Thou shall not take thyself in vain.}

This means taking care of ourselves. Physicians are caregivers. They take care of others, and often put others' needs first. If one sees 25 patients a day, 5 days a week, 48 weeks a year for 25 years, how is that sustainable? An article in The Harvard Business Review ${ }^{14}$ suggested that to perform at high levels over the long haul, one should train in the same systematic, multilevel way that world class athletes do. The authors observed, "The demands on executives to sustain high performance day in and day out, year in and year out, dwarf the challenges faced by any athlete we have ever trained." 14 Sustainability depends as much on how people renew and recover energy as on how they expend it. It is chronic stress without recovery that depletes energy reserves that leads to burnout. The goal is to build secondary competencies like endurance, strength, flexibility, selfcontrol, and focus by attending to the physical, mental, emotional, and spiritual aspects of performance as athletes must do.

In practice, this means actually doing all those healthy things you know you ought to do like paying attention to diet, regular exercise, hydration, and taking breaks during the day.
Corresponding Author: Edward J. Krall, MD; Marshfield Clinic; Behavioral Health Department; 1000 North Oak Avenue; Marshfield WI 54449 USA; Tel: (7I5) 387-575I; Fax: (7I5) 389-3535; Email: krall.edward@marshfieldclinic.org
Received: November 20, 2013

Accepted: November 25, 2013

doi: $10.3121 / \mathrm{cmr} .2013 .1211$ 
A corollary of this is that physicians are role models. The health habits of physicians influence the counseling they provide to their patients and also their credibility. Frank demonstrated that clinicians' preventive health habits influence patients' habits. ${ }^{15} \mathrm{~A}$ physician is not believed if they do not practice what they preach.

\section{Remember what is holy to thee.}

Physician-hood cannot be lived in isolation from total life beliefs. One needs a moral compass. Likewise, the energy that is unleashed by tapping into one's deepest values and defining a strong sense of purpose gives sustenance in the face of adversity and is a powerful source of motivation, determination, and resilience.

- Connect with your purpose. Purpose is an energizing force. It inspires and invigorates. This helps us look at the totality of life rather than the events of the day. True happiness is found in using one's signature strengths in the service of something much larger than the individual. ${ }^{16}$

- Connect with the moment. Pause mindfully before each patient. Mindfulness practice has been shown to reduce burnout. ${ }^{17}$ Meditation is not simply sitting, clearing your head, and chanting. It is focusing attention; finding your center.

- Connect with yourself. It is easy to lose your center when attending to other people all day. Take time every day to quietly reflect, write, or just be present. ${ }^{18}$

- Begin each day with gratitude. Count your blessings daily. Make thankfulness a habit.

\section{Honor thy limits.}

There are limits to the workload we can carry. "I can always do more" is a formula for making one's self and everybody else miserable, because one does not know when to quit. Come to know your limits.

- Create clearer boundaries between work and home. Having electronic medical records can be dangerous. We take our work home, do e-mails and dictations 24/7, much to our demise.

- Deliberately develop a role shedding ritual at the end of the day; hang up the white coat and put away the laptop. Use the drive home to decompress, and greet your family as if you have not seen them for a week. The most precious thing you can give to your patients and your family is your attention.

- Sometimes patients make unreasonable demands. We need to set limits rather than bending over backwards trying to make everyone happy.

\section{VI.Thou shall not work alone.}

We need positive, supportive relationships. Close relationships are a powerful means for promoting positive emotions and effective recovery. Physicians are more likely to burnout when the relationships with the people with whom they work and live fill with conflict. Relationships, spirituality, and work give one a sense of meaning. Attending to relationships at home and at work is vitally important.

How intimate partners treat each other is a powerful determinant of resiliency. There are many adaptations that physicians make to take care of others with long years of training, debt, and long hours. Couples need an optimal amount of time together. ${ }^{19}$

- Preserve your rituals - every couple has little rituals like a weekly date for breakfast or a getaway weekend occasionally. Make these sacred. It is not how much time you give but how much of yourself.

- Share responsibilities at home.

- Do not overleverage financially. Sometimes smaller, simpler, is better.

In the workplace, a key factor that contributes to satisfaction is getting along with the people one works with. ${ }^{20}$ We spend more time at work than we do at home. Yet physicians more often choose a job based primarily on money and geography, then leave because of not getting along with the people with whom they work. ${ }^{21}$

Today physicians practice in silos, hardly having time to talk to colleagues, much less having lunch together, or joining specialty societies. As a result, they deprive themselves of a source of support. The busier one is, the more one needs collegiality.

Collegiality means spending time with colleagues and not seeing them as broken or dysfunctional; being a team builder not destroyer, going to department meetings, having a mentor, being a mentor. ${ }^{22}$ Team building has many benefits. The airline industry has demonstrated that when team members know the first and last names of the people they work with, familiarity trumps fatigue in avoiding mistakes. ${ }^{23}$

\section{VII.Thou shall not kill or take it out on others}

When things go wrong, doctors can get mean. This refers to the hostile work place and how we treat our staff and each other. Having a good medical assistant or nurse can make or break one's day, and these relationships need to be cultivated. Organizations have to set the bar at zero tolerance and be willing to go to the mat in addressing disruptive behavior. Prompt intervention can be career saving. Programs for improving communication and professionalism can be useful. 


\section{Thou shall not work harder. Thou shall work} smarter.

Some physicians continue to do things the same old way and struggle with getting work done. Decreasing stress for electronic health records has been identified as a key in relieving burnout. Using templates and structured documents, getting rid of busy work, unloading activities that do not contribute, all help make one more efficient. What we decide not to do is as important as what we do. Physician peer coaching can also be helpful in identifying opportunities for improvement.

\section{Seek to find joy and mastery in thy work.}

Many of us became doctors because we wanted to help people or make a contribution. ${ }^{24}$ Burnout is about the loss of that passion. We need more than physician satisfaction. We need to rediscover joy in our pursuits - not just survive but thrive. Daniel Pink in his book, Drive ${ }^{25}$ describes that motivation comes not from financial reward but engaging in an activity that is challenging with autonomy, mastery, and purpose.

A Mayo Clinic study confirmed this. Physicians who spend $20 \%$ of their time on an activity felt to be meaningful, whether that is clinical work, community service, or research, were least likely to experience burnout. ${ }^{26}$

\section{$X$.Thou shall continue to learn.}

We are good learners. We are bright people, with lots of interests. We grow and change in our careers. That means periodically reinventing one's self and rediscovering what turns you on. Physicians have found that learning a new skill or going back to school can rekindle passion and growth.

Nearly $50 \%$ of physicians may be facing burnout, but what about the other 50\%? I have seen another story. Some physicians do find happiness in medicine, in spite of the present state of practice and all the changes taking place. They continue to answer the bell, to be present in mind, body, and soul for the welfare of patients, their loved ones, and future physicians, and come away with a sense of satisfaction. This is what young physicians need to see.

\section{Acknowledgements}

The author thanks Marie Fleisner of the Marshfield Clinic Research Foundation for editorial assistance in preparing this manuscript.

\section{References}

1. Shanafelt T. Burnout and satisfaction with work-life balance among US physicians relative to the general US population. Arch Intern Med 2012;172:1377-1385.

2. Dyrbye LN, Massie FS Jr, Eacker A, Harper W, Power D, Durning SJ, Thomas MR, Moutier C, Satele D, Sloan J, Shanafelt TD. Relationship between burnout and professional conduct and attitudes among US medical students. JAMA 2010;304:1173-1180.
3. Shanafelt TD, Balch CM, Bechamps G, Russell T, Dyrbye L, Satele D, Collicott P, Novotny PJ, Sloan J, Freischlag J. Burnout and medical errors among American surgeons. Ann Surg 2010;251:995-1000.

4. Linn LS, Brook RH, Clark VA, Davies AR, Fink A, Kosecoff J. Physician and patient satisfaction as factors related to the organization of internal medicine group practices. Med Care 1985;23:1171-1178.

5. Shanafelt TD, Balch CM, Dyrbye LN, Bechamps G, Russell T, Satele D, Rummans T, Swartz K, Novotny PJ, Sloan J, Oreskovich MR. Special report: suicidal ideation among American surgeons. Arch Surg 2011;146:54-62.

6. Shanafelt TD, Novotny P, Johnson ME, Zhao X, Steensma DP, Lacy MQ, Rubin J, Sloan J. The well-being and personal wellness promotion strategies of medical oncologists in the North Central Cancer Treatment Group. Oncology $2005 ; 86: 23-32$.

7. Shanafelt TD, Sloan JA, Haberman TM. The wellbeing of physicians. Am Med J 2003;114:513-517.

8. Weiner EL, Swain GR, Wolf B, Gottlieb M. A qualitative study of physicians' own wellness promotion practices. West J Med 2001;174:19-23.

9. Linzer M, Levine R, Meltzer D, Poplau S, Warde C, West CP. 10 bold steps to prevent burnout in general internal medicine. $\mathrm{J}$ Gen Intern Med 2014; 29:18-20

10. Vaillant GE, Sobowale NC, McArthur C. Some psychologic vulnerabilities of physicians. N Engl J Med 1972;287: $372-375$.

11. Gabbard GO, Menninger RW. The psychology of postponement in the medical marriage. JAMA1989;261:2378-2381.

12. Gabbard G. The role of compulsiveness in the normal physician. JAMA 1985;254:2926-2929.

13. Sood A. Attention and Interpretation Therapy: A Personal Workbook. Rochester, MN: Morning Dew Publications, LLC; 2009.

14. Loehr J, Shwartz T. The making of a corporate athlete. Harv Bus Rev 2001;79:120-128.

15. Frank E, Rothenberg R, Lewis C, Belodoff BF. Correlates of physicians' prevention-related practices. Findings from the Women Physicians' Health Study. Arch Fam Med 2000;9:359-367.

16. Seligman M. Authentic Happiness. New York: Free Press; 2002.

17. Krasner MS, Epstein RM, Beckman H, Suchman AL, Chapman B, Mooney CJ, Quill TE. Association of an educational program in mindful communication with burnout, empathy, and attitudes among primary care physicians. JAMA 2009;302:1284-1293.

18. Rabow MW, McPhee SJ. Doctoring to heal: fostering wellbeing among physicians through personal reflection. West $\mathbf{J}$ Med 2001;174:66-69.

19. Sotile WM, Sotile MO. Letting Go of What's Holding You Back. Novato, CA: New World Library; 2009.

20. Linzer M, Konrad TR, Douglas J, McMurray JE, Pathman DE, Williams ES, Schwartz MD, Gerrity M, Scheckler W, Bigby JA, Rhodes E. Manage care, time pressure, and physician job satisfaction: results from the physician worklife study. J Gen Intern Med 2000;15:441-450.

21. Stajduhar T. The curse of the first job-fact or urban legend? Jackson \& Coker Industry Report. 2012;5(6) [Editorial].

22. Sargent MC, Sotile W, Sotile MO, Rubash H, Barrak RL. Quality of life during orthopaedic training and academic practice. Part 1: orthopaedic surgery residents and faculty. J Bone Joint Surg Am 2009;91:2395-2405.

23. National Transportation Safety Board. A review of flight-crew involved, major accidents of U.S. air carriers, 1978 through 1990. Safety Study NTSB/SS-94/01. Washington, DC; 1994. 
24. Brown S, Gunderman RB. Viewpoint: enhancing the professional fulfillment of physicians. Acad Med 2006;81:577-582.

25. Pink DH. Drive: The Surprising Truth About What Motivates Us. New York: Penguin Group; 2009.

26. Shanafelt TD, West CP, Sloan JA, Novotny PJ, Poland GA, Menaker R, Rummans TA, Dyrbye LN. Career fit and burnout among academic faculty. Arch Intern Med 2009;169:990-995.

\section{Author Affiliation}

Edward J. Krall, MD; Marshfield Clinic, Behavioral Health Department, 1000 North Oak Avenue, Marshfield, WI 54449 USA 